\title{
IDENTIFICATION OF GENES DIFFERENTIALLY EXPRESSED IN HYPHAE OF CANDIDA ALBICANS
}

\author{
Analy Salles de Azevedo Melo*; Rui Cosme Serafim; Marcelo Ribeiro da Silva Briones \\ Departamento de Microbiologia, Imunologia e Parasitologia, Escola Paulista de Medicina, Universidade Federal de São Paulo, \\ São Paulo, SP, Brasil.
}

This paper corresponds to an "extended abstract" selected for oral presentation in the $22^{\text {nd }}$ Brazilian Congress of Microbiology, held in Florianópolis, SC, Brazil, in November 17-20, 2003

\begin{abstract}
The ability to switch from yeast to hyphal forms is essential for Candida albicans virulence. This morphological switch involves the expression of hyphal-specific genes under the control of transcriptional factors. To contribute to the discovery of hyphal-specific genes, we used a differential screening method where clones of a genomic DNA library were hybridized with yeast and hyphal cDNA probes. Two clones with increased expression in hyphae were selected for study. Sequencing these clones, we found that they encoded two important metabolic genes, CaHXT7 (high-affinity hexose transporter) and CaYLL34 (member of the AAA ATPase family). CaHXT7 and CaYLL34 ORFs were completely determined. Analyses of the putative proteins show that: (1) CaHxt7p has one hexose transporter domain and (2) CaYll34p has two AAA ATPase domains. These results show, for the first time, increased expression of metabolic genes in C. albicans hyphae. Also, because the proteins encoded by CaHXT7 and CaYLL34 may be necessary for the switching to hyphae, they could be new targets for antifungal drugs.
\end{abstract}

Key words: Differential screening, Candida albicans, HXT7, YLL34.

\section{INTRODUCTION}

The yeast Candida albicans is an opportunistic pathogen of humans. Usually, it is commensal and colonizes the mucosal surfaces of the gastrointestinal tract although certain factors, such as host immune-deficiency, may trigger life-threatening disseminated infections (4).

C. albicans can grow in a variety of morphological forms, ranging from budding yeast to pseudohyphae and hyphae, where the latter is a more pathogenic form. Different signaling pathways and transcriptional factors seem to converge to regulate the transcription of a common set of hyphal-specific genes (3). Several genes have been identified whose expression is induced during hyphal growth and most of them encode cellwall proteins. Probably, most of hyphal-specific genes have not yet been identified. Therefore, we used a prospective method, the differential screening, to identify differentially expressed genes in hyphae of $C$. albicans.

\section{MATERIALS AND METHODS}

To obtain Candida albicans genome library, genome DNA of Candida albicans ATCC 90029 was extracted and submitted to ultrasound treatment. The fragments from 1 to $4 \mathrm{~kb}$ were selected and cloned. Plasmids were extracted using "CottonPrep" method, performed in a 96 wells plate using a modified MiniPrep protocol.

C. albicans was grown in YPD media at $30^{\circ} \mathrm{C}$ to produce yeast cells. To obtain hyphal form, yeast cells were diluted in fetal bovine serum containing dextrose and incubated at $37^{\circ} \mathrm{C}$

*Corresponding author. Mailing address: Departamento de Microbiologia, Imunologia e Parasitologia, Escola Paulista de Medicina, Universidade Federal de São Paulo. Rua Botucatu, 862, Ed. Ciências Biomédicas $3^{\circ}$ andar, Vila Clementino. 04023-062, São Paulo, SP, Brasil. Tel.: (+5511) 55764537. Fax: (+5511) 5571-5604. E-mail: analy@ecb.epm.br 
for 3 hours. The total RNA was extracted and cDNA of yeast and hyphae were produced.

In differential screening assay, plasmids were plotted in a Dot Blot membrane. The membrane was hybridized with yeast and hyphae cDNA probes labeled with $\left[\alpha{ }^{-32} \mathrm{P}\right] \mathrm{dCTP}$. The images were analyzed by ImageQuant (Molecular Dynamics) program. The clones of interest were sequenced. As the inserts were greater than $2,000 \mathrm{bp}$, the plasmids were fragmented by ultrasound treatment. The fragments between 300 and 1000 bp were cloned. The inserts were sequenced and the contigs were assembled in Phred Phrap Consed program. The alignments were performed with the MEGALIGN program (DNAstar, Madison, Wisconsin) according to the Clustal method.

\section{RESULTS}

In order to identify genes that are up-regulated during the yeast-to-hypha transition, we used a differential screening method where a dot blot membrane containing clones of $C$. albicans library were hybridized with total cDNA probes of yeast and hyphal form (Fig. 1). The arrows show two clones (G3 and E4) that contain genes with increased expression in hyphal form. When compared with yeast expression, G3 and E4 clones were 1.7 and 3.1 times increased in hyphae, respectively.

Sequencing of these clones, we found that they encoded two important metabolic genes, CaHXT7 (high-affinity hexose transporter) and CaYLL34 (member of the AAAATPase family).
The sequence of each gene was aligned to the homologous in S. cerevisiae and contig of Candida Genome database in order to determine the complete ORF (Figs. 2 and 3). To find the ORFs of contigs G3 and E4, these sequences were submitted to "Find ORF" tool in NCBI site.

CaHXT ORF encode a putative protein of 540 amino acids. Analyzing CaHxt7p on pfam site, a hexose transport domain was found. CaYLL34 ORF encodes a protein of 828 amino acids and on pfam analysis, it presented two domains common to the AAAATPase family.

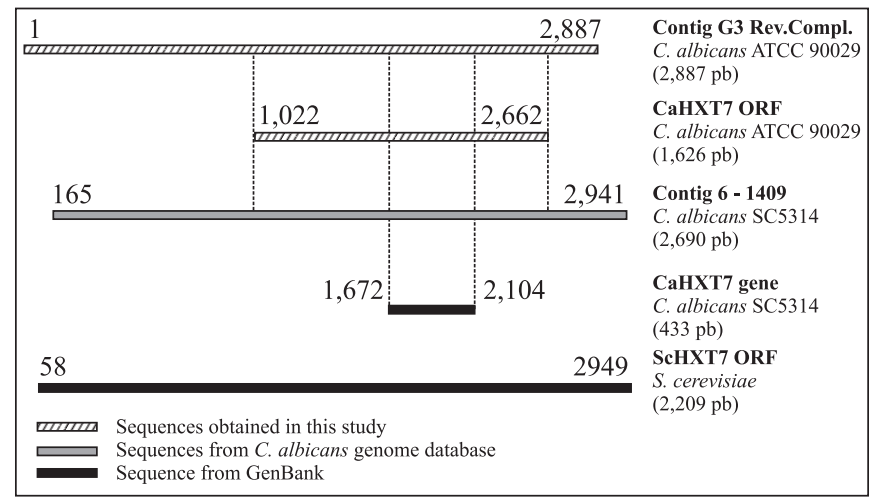

Figure 2. Diagram of aligment of $H X T 7$ genes sequences. These sequences were obtained from two strains: $C$. albicans ATCC 90029 (this study) and C. albicans SC5314 (Candida Stanford Genome).

\section{A) Membrane VII hybridized with hyphal cDNA probes}

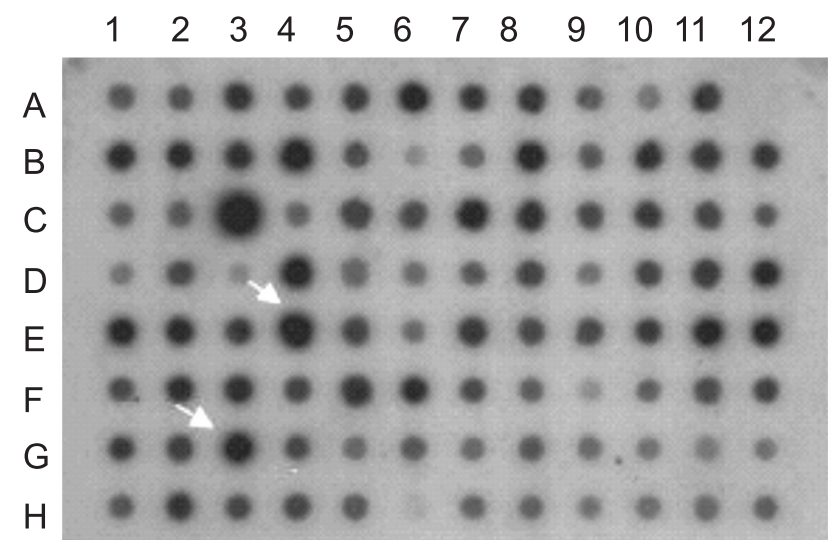

\section{B) Membrane VII hybridized with yeast cDNA probes}

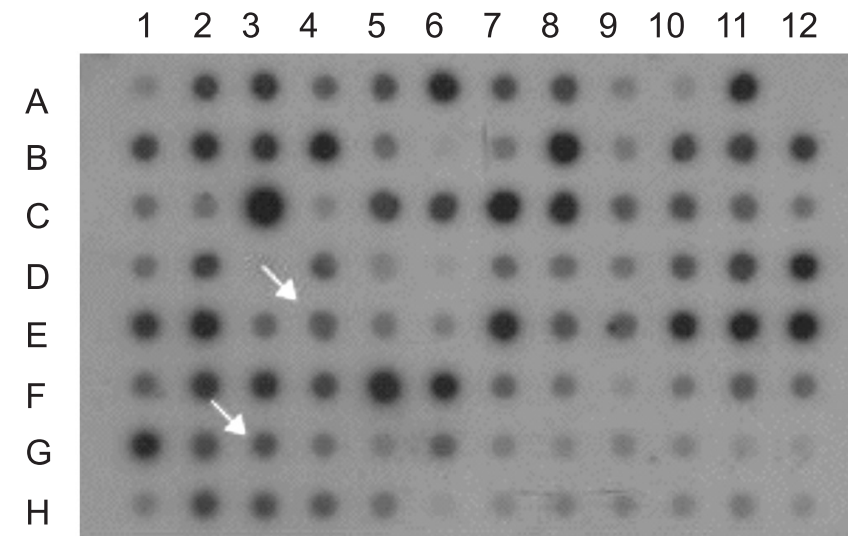

Figure 1. Differential Hybridization. Dot Blot of membrane VII hybridized with hyphae cDNA probes $(\mathbf{A})$ and yeast cDNA probes (B). Each position contains plasmids of C. albicans ATCC 90029 genomic library. A1, D6, H1 and H12 positions contains plasmids from C. Albicans actin gene clone, used as positive control and signal normalization. A12 position constains no plasmid, used as reaction blanc. G12 position contains pUC18 plasmid without insert, used as negative control. The arrows indicate the clones with the genes with increased expression in hyphal from (positions E4 and G3). 


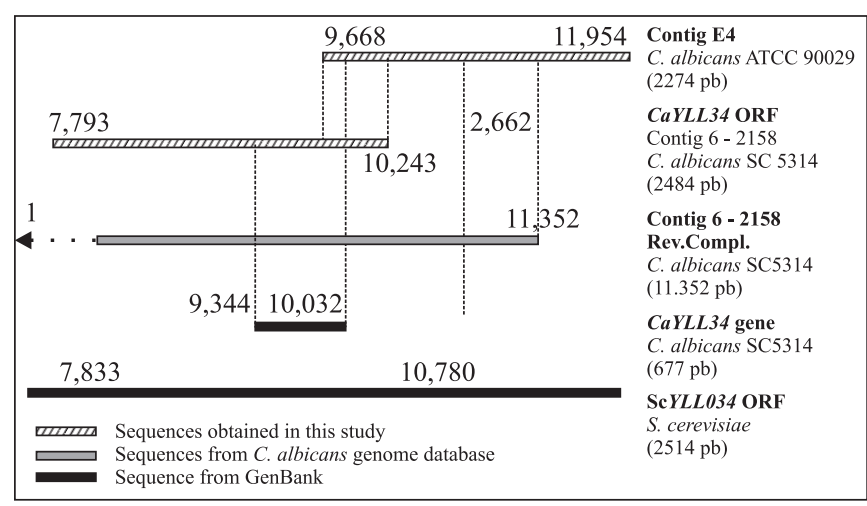

Figure 3. Diagram of aligment of $Y L L 34$ genes sequences. These sequences were obtained from two strains: $C$. albicans ATCC 90029 (this study) and C. albicans SC5314 (Candida Stanford Genome).

\section{DISCUSSION}

Our results suggest that genes CaHxt7 and Hxt7 ( $S$. cerevisiae) are homologous based on their sequence similarity (58.8\%). In S. cerevisiae this gene encodes protein Hxt7, a highaffinity glucose transporter (1). The increased expression of CaHXT7 in C. albicans hyphae could be a response to the low glucose concentration in the microenvironment during tissue invasion.

The ORF CaYLL34 has high sequence similarity to ORF YLLO34c of S. cerevisiae (58.3\%) suggesting that they are homologous. YLLO34c of $S$. cerevisiae is essential for cell growth (2). CaYLL34, as a member of the AAAATPase family, is probably necessary for membrane fusion and protein degradation. Hyphae of $C$. albicans have a great number of vacuoles that contain proteinases necessary to tissue invasion and CaYl134p may have an important role in their fusion and Ub-Pr degradation.

This is the first study reporting the up-regulation of metabolic genes during yeast-hyphae transition. Also because the proteins encoded by these genes may be necessary for the switching yeast to hyphal form, they can be new targets for the development of antifungal drugs.

\section{ACKNOWLEDGMENTS}

A.S.A.M. received fellowship from CNPq. M.R.S.B. received grants from FAPESP and Howard Hughes Medical Institute (USA).

\section{RESUMO}

\section{Identificação de gases em hifa de Candida albicans}

A transição morfológica de levedura para hifa é essencial para a virulência de Candida albicans. Esta transição envolve a expressão de genes hifa-específicos que estão sob o controle de fatores transcricionais. Para descobrir genes hifa-específicos utilizamos um método de triagem diferencial, onde clones de biblioteca de DNA genômico foram hibridizados com sondas de cDNA de levedura e hifa. Dois clones com aumento de expressão em hifa foram selecionados. O sequenciamento dos insertos destes clones permitiu a identificação de dois genes metabólicos importantes: CaHXT7 (high-affinity hexose transporter) e CaYLL34 (da família AAA ATPase). As ORFs completas destes genes foram caracterizadas e a análise das proteínas hipotéticas revelou que: (1) CaHxt7p tem um domínio de transportador de hexose e (2) CaYll34 tem dois domínios AAA ATPase. Este é o primeiro estudo que demonstra aumento de expressão de genes metabólicos em hifas de C. albicans. Ainda, a associação dos produtos de CaHXT7 e CaYLL34 com a formação de hifas torna estas proteínas potenciais novos alvos para drogas antifúngicas.

Palavras-chave: triagem diferencial, Candida albicans, HXT7, YLL34.

\section{REFERENCES}

1. Boles, E.; Hollenberg, C.P. The molecular genetics of hexose transport in yeast. FEMS Microbiol. Rev., 21:85-111, 1997.

2. Dai, R.M.; Li, C.C. Valosin-containing protein is a multi-ubiquitin chain-targeting factor required in ubiquitin-proteasome degradation. Nat. Cell. Biol., 3:740-744, 2001.

3. Liu, H. Transcriptional control of dimorphism in Candida albicans. Curr. Opin. Microbiol., 4:728-735, 2001.

4. Odds, F.C. Candida and candidosis. 2. ed. London, BailliereTrindal, 1988 . 